\title{
Profile of Blended Learning Implementation in Learning Activities
}

\author{
Eka Yulia Syahrawati ${ }^{*}$, Endang Susantini ${ }^{2}$, Sifak Indana ${ }^{3}$ \\ 1,2,3Universitas Negeri Surabaya, Surabaya, Indonesia
}

\begin{tabular}{|c|c|}
\hline (A) Check for updates open 0 access CC) & DOI : https://doi.org/10.46245/ijorer.v3i1.183 \\
\hline Sectio & \multirow{11}{*}{$\begin{array}{l}\text { ABSTRACT } \\
\text { Study aims to describe and analyze of blended learning implementation in } \\
\text { learning activities. The method applied in this research is a literature review } \\
\text { that is sourced from the results of previous studies that have been selected } \\
\text { from Google Scholars. The steps applied in this study are identifying } \\
\text { journals/articles about blended learning, analyzing the definition of blended } \\
\text { learning, synthesizing opportunities and activities in implementation of } \\
\text { blended learning, analyzing barriers to implementing blended learning, and } \\
\text { making conclusions. From the results of the analysis of } 30 \text { selected works of } \\
\text { literature, the implementation of blended learning can be done by teaching it } \\
\text { as a learning model, teaching it by combining it with other learning strategies } \\
\text { or models, teaching it with the help of an LMS, and teaching it with the help of } \\
\text { social media. Furthermore, the application of blended learning is able to } \\
\text { support activities that can train students' } 21 \text { st century skills. The } \\
\text { implementation of blended learning requires careful planning and requires an } \\
\text { understanding of student characteristics and the availability of supporting } \\
\text { facilities and infrastructure. This study can provide an overview of the } \\
\text { opportunities to apply blended learning in learning activities. }\end{array}$} \\
\hline & \\
\hline er 11, 2021 & \\
\hline 6, 2022 & \\
\hline$y 7,2022$ & \\
\hline & \\
\hline & \\
\hline & \\
\hline & \\
\hline & \\
\hline & \\
\hline
\end{tabular}

\section{INTRODUCTION}

The rapid development of access and sources of information requires the world of education to innovate in the learning process. Students need to be trained so that they have skills that are in line with the progress of the times. Relevant skills are needed to successfully adapt and be able to contribute to the 21st century. The abilities of the 21st century include four things known as the 4Cs namely: critical thinking and problem solving, creativity and innovation, communication and collaboration. Education should be able to prepare students to master these various skills (Isbandiyah \& Sanusi, 2019).

In general, the ability to think logically and rationally in students who are still in high school is illustrated through tests organized by PISA (Program for International Student Assessment). The 2018 PISA report released on December 3, 2019, shows that the average score of Indonesian students for science is 396 and $60 \%$ of Indonesian students have science skills below the minimum competency (Kemendikbud, 2019). Based on the results of the PISA test, it can be seen that in general, the ability of Indonesian students is still low and only able to reach the second level of the six levels of thinking in the questions given by PISA (Sani \& Prayitno, 2020). Changes are needed to prepare students so that they can compete with the times. One effort that can be done is to train students' thinking skills through learning that integrates technology because students who have thinking skills will be able to process new information or knowledge so that they can find possible solutions to a problem, as well as the mastery of technology that will make them able to adapt to the times. 
The integration of technology in learning provides benefits such as more flexible learning opportunities without being bound by space and time, as well as supporting students to be able to learn independently. Technology can be used to support the learning process. The advantages offered are not only the ease and speed of accessing information or material content, but also the presence of the media that can make learning more interactive and interesting. For this reason, it is necessary to integrate technology in the learning is implemented in a model or learning method. It can develop student capacity while be able to survive in the era of technological progress. The integration of technology in learning activities and active learning styles is very necessary. Teachers are expected to be able to apply learning that utilizes technology and information facilities and be able to train 21st-century skills. One of the learning activities that are considered capable of training 21st-century skills as well as training students to use technology is blended learning because of the integration of information technology in it. Blended learning is a teaching method that combines face-to-face learning with online learning to create a conducive learning environment so that students learn to be more active and independent (Utomo \& Wihartanti, 2019). Several studies have examined the implementation of blended learning which is considered to have been able to provide positive results on student development. Therefore, this study aims to describe and analyze of blended learning implementation in learning activities through literature study. This study is expected to provide an overview of the opportunities and obstacles in the implementation of blended learning so that it can assist teachers in developing the right blended learning design.

\section{RESEARCH METHOD}

This research is a literature review that aims to describe and analyze of blended learning implementation in learning activities. The study was conducted based on previous studies. This literature study has reviewed thirty articles/journals on blended learning selected from Google Scholar. The articles/journals are studied articles published between 2012 and 2021. The steps taken in the literature study on the implementation of blended learning in this learning activity were adapted from Sukma and Priatna (2021) including (1) identifying journals/articles about blended learning, (2) analyzing the definition of blended learning, (3) synthesizing opportunities and activities in implementing blended learning, (4) analyzing barriers to implementing blended learning, (5) making conclusions. The steps are then outlined in the flow chart as follows Figure 1.

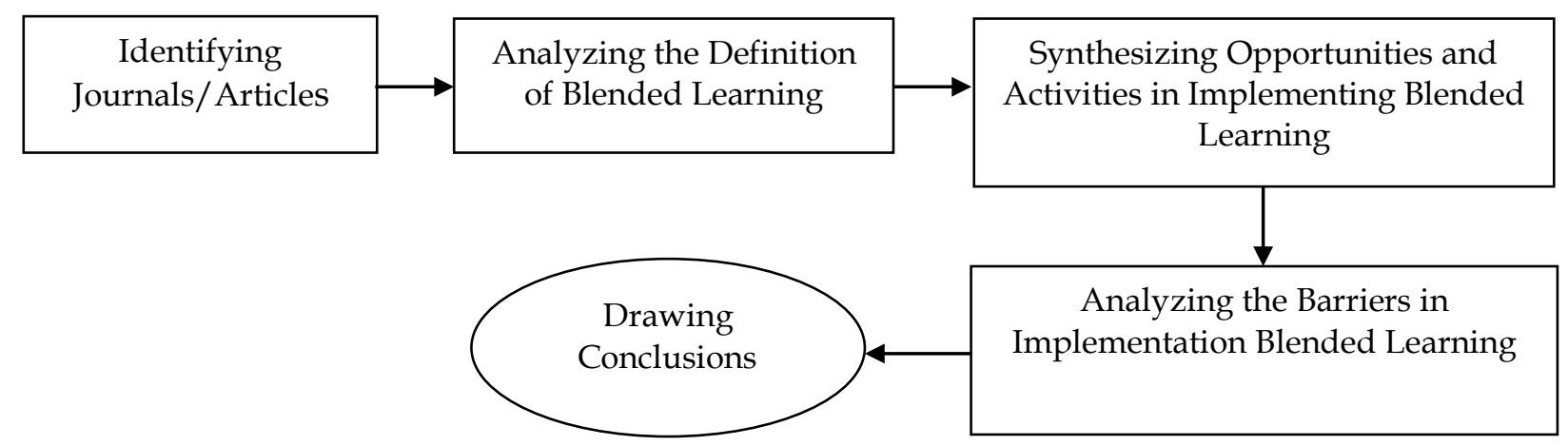

Figure 1. Flowchart research on the profile of blended learning implementation in learning activities. 
RESULTS AND DISCUSSION

Result

Table 1. The literature review of blended learning in learning activities the year 2012-2021.

\begin{tabular}{|c|c|c|c|}
\hline Autor/Year & $\begin{array}{c}\text { Sample } \\
\text { Characteristics }\end{array}$ & Research design & Result \\
\hline (Syarif, 2012) & $\begin{array}{l}\text { The research subjects } \\
\text { were } 57 \text { students of } \\
\text { SMKN } 1 \text { Paringin XI } \\
\text { KRA class, totaling } 30 \\
\text { students in control } \\
\text { class, and XI KRB with } \\
27 \text { students in } \\
\text { Experimental class. }\end{array}$ & $\begin{array}{l}\text { - Quantitative research } \\
\text { with quasi-experimental } \\
\text { approach. } \\
\text { - Data collection using } \\
\text { questionnaires and } \\
\text { multiple-choice tests. }\end{array}$ & $\begin{array}{l}\text { There are significant } \\
\text { differences, both } \\
\text { motivation and student } \\
\text { achievement between } \\
\text { classes that use the } \\
\text { blended learning model } \\
\text { and students in classes } \\
\text { that use the face-to-face } \\
\text { learning model. }\end{array}$ \\
\hline (Sandi, 2012) & $\begin{array}{l}\text { Research subjects were } \\
152 \text { students of State } \\
\text { Senior High School of } 5 \\
\text { Denpasar in class X } \\
\text { which was divided into } \\
4 \text { classes. Two classes as } \\
\text { the experimental class } \\
\text { with } 76 \text { students and } 2 \\
\text { classes as the control } \\
\text { class with } 76 \text { students. }\end{array}$ & $\begin{array}{l}\text { - A quasi-experimental } \\
\text { study using posttest-only } \\
\text { control group design } \\
\text { research. } \\
\text { - Data analyzed using } \\
\text { ANOVA2x2 factorial and } \\
\text { Tukey's test. }\end{array}$ & $\begin{array}{l}\text { - Student independence } \\
\text { plays an important } \\
\text { role in successful } \\
\text { learning, students } \\
\text { with high } \\
\text { independence excel in } \\
\text { blended learning. } \\
\text { - Students with low } \\
\text { independence get } \\
\text { lower results in direct } \\
\text { learning. }\end{array}$ \\
\hline $\begin{array}{l}\text { (Hermawanto } \\
\text { et al., 2013) }\end{array}$ & $\begin{array}{l}\text { Research subjects were } \\
92 \text { students of class X at } \\
\text { State Senior High } \\
\text { School of } 1 \text { Batu. Both } \\
\text { X6 and X10 classes as } \\
\text { the experimental class } \\
\text { with } 46 \text { students, then } \\
\text { both X11 and X12 } \\
\text { classes as the control } \\
\text { classes with } 46 \text { students. }\end{array}$ & $\begin{array}{l}\text { - A quasi-experimental } \\
\text { research used a } \\
\text { randomized posttest-only } \\
\text { control group design. } \\
\text { - Instruments used is the } \\
\text { objective test. } \\
\text { - Data analysis by t-test } \\
\text { then followed by the } \\
\text { turkey test. }\end{array}$ & $\begin{array}{l}\text { Blended learning can } \\
\text { improve the mastery of } \\
\text { physics concepts and } \\
\text { reasoning and train the } \\
\text { students to be } \\
\text { independent and } \\
\text { creative. }\end{array}$ \\
\hline $\begin{array}{l}\text { (Husamah, } \\
\text { 2015) }\end{array}$ & $\begin{array}{l}\text { The research subjects } \\
\text { were } 174 \text { students } \\
\text { majoring in Biology, } \\
\text { FKIP Univ } \\
\text { Muhammadiyah } \\
\text { Malang, 2014/2015 } \\
\text { academic year who } \\
\text { programmed the } \\
\text { Introduction to } \\
\text { Education course, } \\
\text { which consists of } 4 \\
\text { classes, namely: } \\
\text { - Both IA and IB classes } \\
\text { with } 82 \text { students as } \\
\text { experimental classes. } \\
\text { - Both IC and ID classes } \\
\text { with } 92 \text { students as } \\
\text { the control's classes. }\end{array}$ & $\begin{array}{l}\text { - Quasi-experimental } \\
\text { research. } \\
\text { - Data analysis with One- } \\
\text { way ANOVA via SPSS } \\
22 \text {. }\end{array}$ & $\begin{array}{l}\text { The Blended Project- } \\
\text { Based-Learning-model is } \\
\text { successful for } \\
\text { developing the thinking } \\
\text { skills of new students in } \\
\text { the Department of } \\
\text { Biology. }\end{array}$ \\
\hline (Alfi et al., & Research subjects were & - Quasi-experimental & - The implementation of \\
\hline
\end{tabular}




\begin{tabular}{|c|c|c|c|}
\hline Autor/Year & $\begin{array}{c}\text { Sample } \\
\text { Characteristics }\end{array}$ & Research design & Result \\
\hline 2016) & $\begin{array}{l}51 \text { students of class XI } \\
\text { State Senior High } \\
\text { School of } 4 \text { Malang, } \\
\text { namely students in the } \\
\text { XI IPS-1 class with } 25 \\
\text { students as an } \\
\text { experimental class and } \\
\text { students of XI IPS-2 } \\
\text { class with } 26 \text { students as } \\
\text { the control class. }\end{array}$ & $\begin{array}{l}\text { research. } \\
\text { - Test the hypothesis with } \\
\text { the gain score. } \\
\text { - The hypothesis is } \\
\text { analyzed through the } \\
\text { Independent Samples t- } \\
\text { Test with the help of SPSS } \\
\text { 16.0. }\end{array}$ & $\begin{array}{l}\text { problem-based- } \\
\text { learning-model with } \\
\text { blended-learning in } \\
\text { geography, affects } \\
\text { students' critical } \\
\text { thinking skills. } \\
\text { - The average scores of } \\
\text { students' critical } \\
\text { thinking skills in the } \\
\text { Experimental class is } \\
\text { higher than students } \\
\text { in the control class. }\end{array}$ \\
\hline $\begin{array}{l}\text { (Lestari et al., } \\
\text { 2016) }\end{array}$ & $\begin{array}{l}\text { The research subjects in } \\
\text { trial } 1 \text { were } 10 \text { students } \\
\text { of XI natural science } 1 \\
\text { class while the subjects } \\
\text { of trial } 2 \text { were } 40 \\
\text { students of XI natural } \\
\text { science } 2 \text { class. The } \\
\text { study was carried out at } \\
\text { State Senior High } \\
\text { School of } 1 \text { Larangan, } \\
\text { Brebes in the academic } \\
\text { year } 2012 / 2013 \text {. }\end{array}$ & $\begin{array}{l}\text { - Research and } \\
\text { development (R\&D) } \\
\text { using 4-D model. } \\
\text { - The trial used a one- } \\
\text { sample group pretest- } \\
\text { posttest design. } \\
\text { - The learning tools } \\
\text { developed are the } \\
\text { syllabus, the lesson plans, } \\
\text { teaching materials. }\end{array}$ & $\begin{array}{l}\text { Blended learning tools } \\
\text { are able to support } \\
\text { students to think } \\
\text { critically because it } \\
\text { makes students think } \\
\text { thoroughly and raises } \\
\text { critical questions and } \\
\text { answers. }\end{array}$ \\
\hline (Wright, 2017) & $\begin{array}{l}\text { The research subjects } \\
\text { were } 112 \text { students who } \\
\text { programmed the } \\
\text { "communicative } \\
\text { English grammar" } \\
\text { course at the Malaysia } \\
\text { public university }\end{array}$ & $\begin{array}{l}\text { - Research with } \\
\text { quantitative and } \\
\text { qualitative approach } \\
\text { design for triangulation. } \\
\text { - Quantitative data was } \\
\text { generated using } \\
\text { dichotomous and Likert } \\
\text { scale questions which } \\
\text { were analyzed using both } \\
\text { frequency analysis and } \\
\text { descriptive statistics. } \\
\text { - Qualitative data, namely } \\
\text { responses to open-ended } \\
\text { questions, were analyzed } \\
\text { and coded into emerging } \\
\text { categories and sub } \\
\text { categories. } \\
\text { - Aspects of student } \\
\text { feedback investigated } \\
\text { included students' } \\
\text { general preferences } \\
\text { between face-to-face and } \\
\text { online learning, students' } \\
\text { general perceptions of } \\
\text { online learning in terms } \\
\text { of motivation, and } \\
\text { students' general } \\
\text { perceptions of online } \\
\text { learning in terms of } \\
\text { interest. }\end{array}$ & $\begin{array}{l}\text { More students think } \\
\text { that classroom } \\
\text { learning is more } \\
\text { motivating and has a } \\
\text { higher interest, } \\
\text { because better } \\
\text { understanding, valued } \\
\text { the classroom } \\
\text { interactions with } \\
\text { lecturers and fellow } \\
\text { students, the } \\
\text { suggestion from } \\
\text { lecturers. } \\
\text { - Students who prefer } \\
\text { online lessons cite the } \\
\text { speed and the } \\
\text { convenience of } \\
\text { learning and the } \\
\text { flexibility of study } \\
\text { time and place as } \\
\text { reasons for the choice. } \\
\text { The skillful } \\
\text { application of online } \\
\text { learning can increase } \\
\text { mastery in the course } \\
\text { of language material, } \\
\text { but cannot reduce the } \\
\text { role of face-to-face } \\
\text { teaching with teachers. }\end{array}$ \\
\hline (Suana et al., & The research subjects & - The development & The Schoology-based \\
\hline
\end{tabular}




\begin{tabular}{|c|c|c|c|}
\hline Autor/Year & $\begin{array}{c}\text { Sample } \\
\text { Characteristics }\end{array}$ & Research design & Result \\
\hline 2017) & $\begin{array}{l}\text { were } 31 \text { students who } \\
\text { programmed the first } \\
\text { basic of physics course } \\
\text { at the Department of } \\
\text { Physics, FKIP, } \\
\text { University of Lampung }\end{array}$ & $\begin{array}{l}\text { research using the } \\
\text { ADDIE model. }\end{array}$ & $\begin{array}{l}\text { learning media that have } \\
\text { been developed is } \\
\text { declared effective and } \\
\text { valid as a blended } \\
\text { learning media in the } \\
\text { Basic Course of Physics-I. }\end{array}$ \\
\hline $\begin{array}{l}\text { (Widana et } \\
\text { al., 2018) }\end{array}$ & $\begin{array}{l}\text { The research subjects } \\
\text { were } 65 \text { students of } \\
\text { class } X \text { natural science } \\
\text { state senior high school } \\
1 \text { Mengwi. The X } \\
\text { natural science } 6 \text { class } \\
\text { with } 30 \text { students as the } \\
\text { experimental class and } \\
X \text { natural science } 7 \text { class } \\
\text { with } 35 \text { students as the } \\
\text { control class. }\end{array}$ & $\begin{array}{l}\text { - Quasi-experimental } \\
\text { research. } \\
\text { - Trial design with non- } \\
\text { equivalent posttest-only } \\
\text { control group design. } \\
\text { - The type of quantitative } \\
\text { data is the score of critical } \\
\text { thinking skills, through } \\
\text { questionnaires and } \\
\text { learning outcomes. } \\
\text { - Data was analyzed } \\
\text { through the t-test and } \\
\text { MANOVA test with the } \\
\text { SPSS 15.0. }\end{array}$ & $\begin{array}{l}\text { - A blended learning } \\
\text { model assisted by } \\
\text { digital comics can } \\
\text { improve critical } \\
\text { thinking skills and } \\
\text { learning outcomes } \\
\text { - A blended learning } \\
\text { model assisted by } \\
\text { digital comics } \\
\text { gradually improves } \\
\text { critical thinking skills } \\
\text { and biology learning } \\
\text { outcomes. }\end{array}$ \\
\hline $\begin{array}{l}\text { (Farida \& } \\
\text { Indah, 2018) }\end{array}$ & $\begin{array}{l}\text { Research subjects was } \\
\text { students who } \\
\text { programmed Calculus } 1 \\
\text { course majoring in } \\
\text { Informatics Engineering } \\
\text { STMIK Duta-Bangsa for } \\
2017 / 2018 \text { academic } \\
\text { year. }\end{array}$ & $\begin{array}{l}\text { - Classroom action } \\
\text { research referring to } \\
\text { Stephen Kemmis and } \\
\text { Robin Mc Taggart. } \\
\text { - It is carried out in two } \\
\text { cycles, and each cycle is } \\
\text { carried out in two } \\
\text { meetings. } \\
\text { - Each cycle consists of } \\
\text { four steps, namely } \\
\text { preparation, action, } \\
\text { observation, evaluation, } \\
\text { analysis, and reflection. } \\
\text { - Data collection by tests } \\
\text { and observations. } \\
\text { - Data was analyzed using } \\
\text { a quantitative-descriptive } \\
\text { approach. }\end{array}$ & $\begin{array}{l}\text { - The implementation of } \\
\text { blended learning can } \\
\text { increase student } \\
\text { learning } \\
\text { independence. } \\
\text { - The blended learning } \\
\text { strategy capable to } \\
\text { increase students' } \\
\text { critical thinking skills } \\
\text { by } 12.4 \% \text { and by } 91.2 \% \\
\text { after the cycle ends. }\end{array}$ \\
\hline $\begin{array}{l}\text { (Ningsih et } \\
\text { al., 2018) }\end{array}$ & $\begin{array}{l}\text { Research subjects were } \\
65 \text { students in the XII } \\
\text { science class State } \\
\text { Senior High School of } 5 \\
\text { Metro, the sample was } \\
\text { selected by purposive } \\
\text { sampling, namely XII } \\
\text { science } 1 \text { with } 32 \\
\text { students as the } \\
\text { experimental class and } \\
\text { XII science } 2 \text { with } 33 \\
\text { students as the control } \\
\text { class. }\end{array}$ & $\begin{array}{l}\text { - The research design have } \\
\text { been used a Non- } \\
\text { equivalent control group } \\
\text { design. } \\
\text { - Learning is done the face- } \\
\text { to-face for } 4 \text { meetings and } \\
\text { online learning for } 8 \\
\text { meetings (4 times before } \\
\text { and after face-to-face for } \\
60 \text { minutes). } \\
\text { - In the control class, there } \\
\text { are only } 4 \text { face-to-face } \\
\text { learning sessions. } \\
\text { - Data collection using } \\
\text { multiple-choice tests. }\end{array}$ & $\begin{array}{l}\text { - There is a significant } \\
\text { difference in the } \\
\text { average value of } \\
\text { students' critical } \\
\text { thinking skills of the } \\
\text { control class and } \\
\text { experiment class } \\
\text { students. } \\
\text { - The implementation of } \\
\text { Schoology-based on } \\
\text { blended learning has a } \\
\text { significant influence } \\
\text { on critical thinking } \\
\text { ability. }\end{array}$ \\
\hline
\end{tabular}




\begin{tabular}{|c|c|c|c|}
\hline Autor/Year & $\begin{array}{c}\text { Sample } \\
\text { Characteristics }\end{array}$ & Research design & Result \\
\hline $\begin{array}{l}\text { (Ramdani \& } \\
\text { Badriah, 2018) }\end{array}$ & $\begin{array}{l}\text { The research subjects } \\
\text { were } 34 \text { students of } \\
\text { class } C \text { in the fourth } \\
\text { semester in the study } \\
\text { program of biology } \\
\text { education at Siliwangi } \\
\text { University in 2017. }\end{array}$ & $\begin{array}{l}\text { - Data analysis using N- } \\
\text { Gain Test and } \\
\text { Independent Sample T- } \\
\text { test. } \\
\text { - Correlational research. } \\
\text { - Data collection } \\
\text { techniques were carried } \\
\text { out through tests (12 } \\
\text { essay questions to } \\
\text { measure critical thinking } \\
\text { skills, and } 34 \text { multiple } \\
\text { choice questions intended } \\
\text { to determine the student } \\
\text { learning outcomes). } \\
\text { - The data analysis } \\
\text { technique used } \\
\text { correlation regression } \\
\text { with } 0.05 .\end{array}$ & $\begin{array}{l}\text { - There is a positive } \\
\text { influence, both critical } \\
\text { thinking ability and } \\
\text { student learning } \\
\text { values through a } \\
\text { guided-inquiry-model } \\
\text { based on blended- } \\
\text { learning on the human } \\
\text { respiratory system } \\
\text { material. } \\
\text { - If students have high } \\
\text { critical thinking skills, } \\
\text { their learning } \\
\text { outcomes will also } \\
\text { increase. }\end{array}$ \\
\hline $\begin{array}{l}\text { (Setyoko \& } \\
\text { Indriaty, } \\
2018 \text { ) }\end{array}$ & $\begin{array}{l}\text { The research subjects } \\
\text { were } 50 \text { sixth-semester } \\
\text { students who } \\
\text { programmed animal } \\
\text { ecology courses at the } \\
\text { Department of Biology, } \\
\text { FKIP, Samudra } \\
\text { University in 2018. They } \\
\text { were divided into } 2 \\
\text { units: the first unit with } \\
20 \text { students as the } \\
\text { control class and the } \\
\text { seconds unit with } 30 \\
\text { students as the } \\
\text { experimental class. }\end{array}$ & $\begin{array}{l}\text { - Quasi-experimental } \\
\text { research used Non- } \\
\text { Equivalent Control } \\
\text { Group Pretest-Posttest } \\
\text { Design. } \\
\text { - The research instrument } \\
\text { that has been used } \\
\text { cognitive tests in the form } \\
\text { of essay questions and } \\
\text { learning motivation } \\
\text { questionnaires using the } \\
\text { ARCS questionnaire. } \\
\text { - The hypothesis has been } \\
\text { tested with prerequisite } \\
\text { test for normality data } \\
\text { and the paired sample t- } \\
\text { test. }\end{array}$ & $\begin{array}{l}\text { There was a significant } \\
\text { improved in learning } \\
\text { outcomes in aspects of } \\
\text { student knowledge } \\
\text { through Problem-Based- } \\
\text { Learning based on } \\
\text { Blended-learning. }\end{array}$ \\
\hline $\begin{array}{l}\text { (Suana et al., } \\
\text { 2019a) }\end{array}$ & $\begin{array}{l}\text { The research subjects } \\
\text { were } 60 \text { students of } \\
\text { class XII MIA SMA } \\
\text { Negeri } 1 \text { Kalianda, } \\
\text { South Lampung in the } \\
\text { 2018/2019 academic } \\
\text { year. XII MIA } 1 \text { class } \\
\text { with } 32 \text { students as the } \\
\text { experimental class and } \\
\text { XII MIA } 2 \text { class with } 28 \\
\text { students as the control } \\
\text { class. }\end{array}$ & $\begin{array}{l}\text { - Quasi-experimental } \\
\text { research. } \\
\text { - Research design is } \\
\text { Pretest-Posttest Control } \\
\text { Group Design. } \\
\text { - Data was tested by N- } \\
\text { gain analysis, normality- } \\
\text { test, homogeneity-test, } \\
\text { and the Mann-Whitney U } \\
\text { test. }\end{array}$ & $\begin{array}{l}\text { - There is a real } \\
\text { difference in students' } \\
\text { critical thinking skills } \\
\text { after applying blended } \\
\text { learning to static } \\
\text { electricity material } \\
\text { compared to direct } \\
\text { learning. } \\
\text { - The implementation of } \\
\text { blended learning can } \\
\text { increase students' } \\
\text { critical thinking } \\
\text { ability. }\end{array}$ \\
\hline $\begin{array}{l}\text { (Anggraeni et } \\
\text { al., 2019) }\end{array}$ & $\begin{array}{l}\text { A research subjects } \\
\text { were } 68 \text { students of the } \\
X \text { class at SMA Negeri } 5 \\
\text { Malang. Subjects were } \\
\text { determined using the }\end{array}$ & $\begin{array}{l}\text { - Quasi-experimental } \\
\text { research. } \\
\text { - The research design that } \\
\text { has been used is the } \\
\text { posttest-only control }\end{array}$ & $\begin{array}{l}\text { There is a real influence } \\
\text { on students' critical } \\
\text { thinking ability in the } \\
\text { matter of temperature } \\
\text { and heat through }\end{array}$ \\
\hline
\end{tabular}




\begin{tabular}{|c|c|c|c|}
\hline Autor/Year & $\begin{array}{c}\text { Sample } \\
\text { Characteristics }\end{array}$ & Research design & Result \\
\hline & $\begin{array}{l}\text { purposive sampling } \\
\text { technique so that Class } \\
\text { XI G-3 ( } 34 \text { students) was } \\
\text { obtained as the control } \\
\text { class and class XI H-3 } \\
\text { (34 students) was the } \\
\text { experimental class. }\end{array}$ & $\begin{array}{l}\text { group design through } \\
\text { quantitatively analyzed. }\end{array}$ & $\begin{array}{l}\text { Schoology assisted } \\
\text { blended learning. }\end{array}$ \\
\hline $\begin{array}{l}\text { (Suana et al., } \\
2019 b \text { ) }\end{array}$ & $\begin{array}{l}\text { Research subjects are } \\
\text { class XII MIA then two } \\
\text { classes as samples are } \\
\text { determined using the } \\
\text { purposive sampling } \\
\text { technique (one class as } \\
\text { the experimental class } \\
\text { and one class as the } \\
\text { control class). }\end{array}$ & $\begin{array}{l}\text { - A quasi-experimental } \\
\text { research used non- } \\
\text { equivalent control group } \\
\text { design. } \\
\text { - Research data was } \\
\text { collected through tests. } \\
\text { - Data analysis using } \\
\text { independent sample t- } \\
\text { test. }\end{array}$ & $\begin{array}{l}\text { The use of WhatsApp- } \\
\text { assisted in blended } \\
\text { learning increase } \\
\text { students critical thinking } \\
\text { skills and problem- } \\
\text { solving abilities. }\end{array}$ \\
\hline $\begin{array}{l}\text { (Utomo \& } \\
\text { Wihartanti, } \\
\text { 2019) }\end{array}$ & $\begin{array}{l}\text { Research subjects were } \\
35 \text { students who took } \\
\text { the Study and Learning } \\
\text { course in the } \\
\text { Accounting Education } \\
\text { Study Program, the } \\
\text { PGRI Madiun } \\
\text { University in 2018/2019 } \\
\text { academic year. }\end{array}$ & $\begin{array}{l}\text { - Classroom Action } \\
\text { Research (CAR) was } \\
\text { implemented in } 3 \text { cycles. } \\
\text { - Research data was } \\
\text { obtained from the } \\
\text { assessment of lecturer } \\
\text { learning activities and } \\
\text { student learning activities } \\
\text { through observation } \\
\text { sheets and learning } \\
\text { outcomes measured } \\
\text { through tests. }\end{array}$ & $\begin{array}{l}\text { The implementation of } \\
\text { blended learning- } \\
\text { strategy is successful to } \\
\text { improve critical thinking } \\
\text { skills and results student } \\
\text { study. }\end{array}$ \\
\hline $\begin{array}{l}\text { (Sari \& } \\
\text { Wahyudin, } \\
\text { 2019) }\end{array}$ & $\begin{array}{l}\text { Research subjects were } \\
116 \text { undergraduate } \\
\text { students who took } \\
\text { general courses in } \\
\text { English for Business at } \\
\text { Faculty Engineering } \\
\text { and Computer Science, } \\
\text { Universitas Teknokrat } \\
\text { Indonesia. }\end{array}$ & $\begin{array}{l}\text { - Qualitative research. } \\
\text { - Data is from } \\
\text { observations, } \\
\text { questionnaires, and } \\
\text { interviews, then analyzed } \\
\text { quantitatively and } \\
\text { qualitatively. }\end{array}$ & $\begin{array}{l}\text { Most students show the } \\
\text { high positive perception, } \\
\text { in the use of Instagram in } \\
\text { blended learning, } \\
\text { Instagram affects } \\
\text { motivation, } \\
\text { involvements, and } \\
\text { attitude. }\end{array}$ \\
\hline $\begin{array}{l}\text { (Ardianti et } \\
\text { al., 2019) }\end{array}$ & $\begin{array}{l}\text { The research subjects } \\
\text { were } 54 \text { students in the } \\
\text { XI science class at State } \\
\text { Senior High School of } 3 \\
\text { Sumbawa Besar in } \\
\text { 2018/2019 academic } \\
\text { year which was carried } \\
\text { out with one class with } \\
27 \text { students as the } \\
\text { experiment class and } \\
\text { one class with } 27 \\
\text { students as the control } \\
\text { class. }\end{array}$ & $\begin{array}{l}\text { - Quasi-experimental } \\
\text { research used the Posttest } \\
\text { Only Control Group } \\
\text { Design. } \\
\text { - The form of the test used } \\
\text { is in the form of the } \\
\text { description of the type of } \\
\text { critical thinking skill. }\end{array}$ & $\begin{array}{l}\text { There is significant } \\
\text { difference in } \\
\text { effectiveness at learning } \\
\text { that applies blended } \\
\text { learning through STEM } \\
\text { assisted of Schoology } \\
\text { compared to Traditional } \\
\text { Learning. }\end{array}$ \\
\hline $\begin{array}{l}\text { (Astuti \& } \\
\text { Novita, 2019) }\end{array}$ & $\begin{array}{l}\text { The research subject is } \\
\text { literature from various } \\
\text { sources, journals, and } \\
\text { books }\end{array}$ & $\begin{array}{l}\text { Research through literature } \\
\text { review. }\end{array}$ & $\begin{array}{l}\text { Learning designed with } \\
\text { a blended learning } \\
\text { model can improve } \\
\text { mathematical }\end{array}$ \\
\hline
\end{tabular}




\begin{tabular}{|c|c|c|c|}
\hline Autor/Year & $\begin{array}{c}\text { Sample } \\
\text { Characteristics }\end{array}$ & Research design & Result \\
\hline $\begin{array}{l}\text { (Yustina et al., } \\
2020 \text { ) }\end{array}$ & $\begin{array}{l}\text { Research subjects are } 76 \\
\text { students at the } 5 \text { th } \\
\text { semester majoring in } \\
\text { biology education at } \\
\text { Riau University for } \\
2019 / 2020 \text { academic } \\
\text { year, followed by class } \\
\text { VA ( } 38 \text { students) as the } \\
\text { experimental class and } \\
\text { class VB ( } 38 \text { students) as } \\
\text { the control class. }\end{array}$ & $\begin{array}{l}\text { - Quasi-experimental } \\
\text { research used the pretest- } \\
\text { posttest group design. } \\
\text { - The research parameter is } \\
\text { creative thinking with } 4 \\
\text { indicators. } \\
\text { - Data collection using } \\
\text { pretest and posttest } \\
\text { assessment. } \\
\text { - Data was presented and } \\
\text { analyzed descriptively. }\end{array}$ & $\begin{array}{l}\text { communication skills. } \\
\text { - Blended learning and } \\
\text { Project-Based } \\
\text { Learning are enough } \\
\text { to play a role in } \\
\text { improving the creative } \\
\text { thinking-skills of } \\
\text { prospective biology } \\
\text { teachers, } \\
\text { - Both BL and PjBL are } \\
\text { quite effective } \\
\text { compared to } \\
\text { conventional learning } \\
\text { in improving the } \\
\text { creative thinking } \\
\text { ability of prospective } \\
\text { teachers in biology } \\
\text { learning }\end{array}$ \\
\hline $\begin{array}{l}\text { (Marnita et } \\
\text { al., 2020) }\end{array}$ & $\begin{array}{l}\text { The research subjects } \\
\text { were } 3^{\text {rd-semester }} \\
\text { students who } \\
\text { programmed the } \\
\text { thermodynamic's } \\
\text { course majoring in } \\
\text { physics education, FKIP } \\
\text { Almuslim university for } \\
\text { the } 2019 / 2020 \text { academic } \\
\text { year. }\end{array}$ & $\begin{array}{l}\text { - Quasi-experimental } \\
\text { research. } \\
\text { - Data analysis using a } \\
\text { one-sided t-test. }\end{array}$ & $\begin{array}{l}\text { - The implementation of } \\
\text { the Problem-Based- } \\
\text { Instruction-model } \\
\text { based on Blended } \\
\text { learning can increase } \\
\text { students' critical } \\
\text { thinking skills. } \\
\text { - The response of } \\
\text { students to the } \\
\text { implementation of the } \\
\text { Problem-Based- } \\
\text { Instruction-Model } \\
\text { based on Blended- } \\
\text { Learning is the } \\
\text { category of being very } \\
\text { happy with the } \\
\text { ongoing learning. }\end{array}$ \\
\hline $\begin{array}{l}\text { (Nirahua et } \\
\text { al., 2020) }\end{array}$ & $\begin{array}{l}\text { The research subjects } \\
\text { were } 30 \text { students who } \\
\text { programmed } \\
\text { astrophysics courses in } \\
\text { the physic's education } \\
\text { department, FKIP } \\
\text { Pattimura University, } \\
\text { for the } 2019 / 2020 \\
\text { academic year. }\end{array}$ & $\begin{array}{l}\text { - Development research } \\
\text { that has used the 4-D } \\
\text { development model. } \\
\text { - The data analysis has } \\
\text { used descriptive and } \\
\text { quantitative analysis } \\
\text { techniques. }\end{array}$ & $\begin{array}{l}\text { The development of } \\
\text { blended learning-based } \\
\text { astrophysics teaching } \\
\text { materials and critical } \\
\text { thinking skills, feasible } \\
\text { and can be used to coach } \\
\text { students' critical thinking } \\
\text { ability in astrophysics } \\
\text { courses }\end{array}$ \\
\hline $\begin{array}{l}\text { (Wahyunita \& } \\
\text { Subroto, 2021) }\end{array}$ & $\begin{array}{l}\text { The research subjects } \\
\text { were } 30 \text { students of } \\
\text { class XI social science } 3 \\
\text { State Senior High } \\
\text { School of } 1 \text { Puri, } \\
\text { Mojokerto in the } \\
\text { academic year } \\
\text { 2020/2021. }\end{array}$ & $\begin{array}{l}\text { - Quasi-experimental } \\
\text { research with one-group } \\
\text { pretest-posttest design. } \\
\text { - The results obtained are } \\
\text { from the implementation } \\
\text { of learning sheets, critical } \\
\text { thinking skill's tests, and } \\
\text { student responses. }\end{array}$ & $\begin{array}{l}\text { The blended learning } \\
\text { model through the } \\
\text { STEM approach both } \\
\text { significantly and } \\
\text { effectively increase } \\
\text { students' critical } \\
\text { thinking ability. }\end{array}$ \\
\hline $\begin{array}{l}\text { (Susilowati et } \\
\text { al., 2021) }\end{array}$ & $\begin{array}{l}\text { The research subjects } \\
\text { were } 50 \text { physics teacher } \\
\text { candidates, where one }\end{array}$ & $\begin{array}{l}\text { - Quasi-experimental } \\
\text { research used the pretest- } \\
\text { posttest control group }\end{array}$ & $\begin{array}{l}\text { There is a significant } \\
\text { correlation between both } \\
\text { creative thinking skills }\end{array}$ \\
\hline
\end{tabular}




\begin{tabular}{|c|c|c|c|}
\hline Autor/Year & $\begin{array}{c}\text { Sample } \\
\text { Characteristics }\end{array}$ & Research design & Result \\
\hline $\begin{array}{l}\text { (Putra \& } \\
\text { Fitrayati, } \\
2021)\end{array}$ & $\begin{array}{l}\text { class ( } 25 \text { students) was } \\
\text { the experimental class, } \\
\text { and one class ( } 25 \\
\text { students) was the } \\
\text { control class. } \\
\text { The research subjects } \\
\text { were } 30 \text { students of XI } \\
\text { social science } 2 \text { class at } \\
\text { State Senior High } \\
\text { School of } 1 \text { Rengel, } \\
\text { Tuban for the academic } \\
\text { year } 2020 / 2021 \text {. }\end{array}$ & $\begin{array}{l}\text { design. } \\
\text { - Data collection } \\
\text { techniques using essay } \\
\text { tests. } \\
\text { - Data analysis technique } \\
\text { using N-Gain analysis. } \\
\text { - Quasi-experimental } \\
\text { research used one group } \\
\text { pretest-posttest design. } \\
\text { - Blended learning } \\
\text { implemented in this } \\
\text { research is blended } \\
\text { learning rotation. } \\
\text { - Learning is carried out in } \\
2 \text { meetings, (1 online } \\
\text { meeting and } 1 \text { face-to- } \\
\text { face meeting). }\end{array}$ & $\begin{array}{l}\text { Blended learning is } \\
\text { successful in increase } \\
\text { students' critical } \\
\text { thinking ability. }\end{array}$ \\
\hline $\begin{array}{l}\text { (Sukma \& } \\
\text { Priatna, 2021) }\end{array}$ & $\begin{array}{l}\text { The research subjects } \\
\text { are } 18 \text { articles/journals } \\
\text { that examine blended } \\
\text { learning and critical } \\
\text { thinking sourced from } \\
\text { Google Scholar. }\end{array}$ & $\begin{array}{l}\text { Research through literature } \\
\text { review. }\end{array}$ & $\begin{array}{l}\text { - Blended learning is } \\
\text { able to support all } \\
\text { activities needed to } \\
\text { improve students' } \\
\text { critical thinking } \\
\text { ability. } \\
\text { - The implementation of } \\
\text { blended learning in } \\
\text { the Mathematic class } \\
\text { has the opportunity to } \\
\text { increase students } \\
\text { critical thinking skills. }\end{array}$ \\
\hline $\begin{array}{l}\text { (Yennita \& } \\
\text { Zukmadini, } \\
\text { 2021) }\end{array}$ & $\begin{array}{l}\text { The research subjects } \\
\text { were } 30 \text { students who } \\
\text { programmed } \\
\text { biochemistry courses at } \\
\text { the Biology Education } \\
\text { Undergraduate Study } \\
\text { Program in the } \\
\text { University of Bengkulu, } \\
\text { in } 2019 \text {. }\end{array}$ & $\begin{array}{l}\text { - Classroom action } \\
\text { research, conducted in } \\
\text { two cycles. } \\
\text { - Each cycle consists of } \\
\text { four stages, namely } \\
\text { planning, } \\
\text { implementation, } \\
\text { observation, and } \\
\text { reflection. } \\
\text { - The instruments used are } \\
\text { critical thinking test- } \\
\text { sheets and observation- } \\
\text { sheets. } \\
\text { - Analysis of data with } \\
\text { percentages to determine } \\
\text { the criteria for critical } \\
\text { thinking skills }\end{array}$ & $\begin{array}{l}\text { Problem-based learning } \\
\text { that is carried out } \\
\text { through the blended } \\
\text { learning method can } \\
\text { increase student } \\
\text { learning activities, } \\
\text { lecturer teaching } \\
\text { activities and students' } \\
\text { critical thinking skills. }\end{array}$ \\
\hline $\begin{array}{l}\text { (Sugiarti et } \\
\text { al., 2021) }\end{array}$ & $\begin{array}{l}\text { The research subjects } \\
\text { were } 35 \text { second- } \\
\text { semester students } \\
\text { majoring in science } \\
\text { education at the State } \\
\text { University of Malang. }\end{array}$ & $\begin{array}{l}\text { - Development research. } \\
\text { The development model } \\
\text { used refers to Lee \& } \\
\text { Owens which has five } \\
\text { steps namely analysis, } \\
\text { design, development, } \\
\text { implementation, and } \\
\text { evaluation. }\end{array}$ & $\begin{array}{l}\text { E-learning teaching } \\
\text { materials with } \\
\text { electrolyte solutions and } \\
\text { non-electrolyte solutions } \\
\text { and colligative } \\
\text { properties of solutions } \\
\text { are effective in } \\
\text { improving students' }\end{array}$ \\
\hline
\end{tabular}




\begin{tabular}{|c|c|c|c|}
\hline Autor/Year & $\begin{array}{c}\text { Sample } \\
\text { Characteristics }\end{array}$ & Research design & Result \\
\hline & & $\begin{array}{l}\text { - The instruments used are } \\
\text { questionnaires and } \\
\text { questions. } \\
\text { - Data analysis using the } \\
\text { percentage technique to } \\
\text { determine the feasibility } \\
\text { of the developed product. }\end{array}$ & critical thinking ability. \\
\hline $\begin{array}{l}\text { (Aji et al., } \\
2021)\end{array}$ & $\begin{array}{l}\text { The research subjects } \\
\text { are seventh-grade } \\
\text { students at SMPIT } \\
\text { Harapan Bunda } \\
\text { Semarang. }\end{array}$ & $\begin{array}{l}\text { Experimental research } \\
\text { used the pretest-posttest } \\
\text { control group design. } \\
\text { - Data collecting } \\
\text { techniques through tests. } \\
\text { - Data analysis using } \\
\text { completeness analysis of } \\
\text { learning outcomes, N- } \\
\text { gain test, and t-test. }\end{array}$ & $\begin{array}{l}\text { The applications of } \\
\text { blended learning in } \\
\text { science learning about } \\
\text { temperature and its } \\
\text { changes in junior high } \\
\text { school, effectively } \\
\text { improves students' } \\
\text { cognitive learning } \\
\text { outcomes. }\end{array}$ \\
\hline
\end{tabular}

\section{Discussion}

\section{Definition of Blended Learning}

Blended learning is a teaching method that integrates both offline-learning and onlinelearning with the aim of producing a conducive learning environment so that students become more active and independent (Utomo \& Wihartanti, 2019). In this case, what is meant by offline-learning is learning that is more directed at traditional classroom settings while online learning is learning that utilizes the internet or intranet (Singh \& Reed, 2001). The hallmark of blended learning is the existence of an online learning environment that utilizes educational technology. The educational technology that is widely used in the implementation of blended learning is the Learning Management System (LMS). LMS is an application or software that requires an internet connection that can be used by teachers to create virtual classes in online learning. Some examples of LMS that are widely used in blended learning implemented in schools and universities for examples Google Classroom, Edmodo, Schoology, Moodle, and others (Sugiarti et al., 2021; Ardianti et al., 2019; Anggraeni et al., 2019; Suana et al., 2019a; Ningsih et al., 2018; Hermawanto et al., 2013; Sandi, 2012). Based on previous research, the existence of an online learning environment makes blended learning a fun teaching method for students (Marnita et al., 2020) because it has time flexibility in learning (Wright, 2017).

Blended learning is a learning method that can be used as a solution to the limited learning time in face-to-face classes (Astuti \& Novita, 2019). Blended learning can be used to extend learning time in face-to-face classes (Ningsih et al., 2018), in addition, the online learning environment in blended learning can also be used to help students stay connected and discuss anytime and anywhere (Suana et al., 2019b; Anggraeni et al., 2019). Discussion activities can be carried out through LMS or social media as agreed between teachers and students. Discussions can be carried out between fellow students or between students and teachers (Anggraeni et al., 2019). Focused discussions can increase motivation and help in learning (Syarif, 2012; Setyoko \& Indriaty, 2018). Based on previous research, it can be concluded that blended learning is a style of learning that harmoniously integrate the advantages of face-to-face learning with online 
learning, as well as the support from the use of various information technology-based media so that it can assist students in learning.

\section{Characteristics and Opportunities in the Implementation of Blended Learning}

Blended learning is a learning process that combines face-to-face classroom learning with online learning that uses the internet to achieve learning objectives (Putra \& Fitrayati, 2021). Based on a study of 30 articles that have been carried out, including 12 articles on blended learning at the school level (senior high school), 12 articles on blended learning at the university level, four articles on developing blended learning tools and two articles on literature review of blended learning.

Based on previous research, there are various techniques for implementing blended learning in learning that has been carried out at both the school and university levels. The forms of application of blended learning that is mostly carried out include blended learning as a learning model (Putra \& Fitrayati, 2021; Widana et al., 2018); blended learning is taught by combining strategies or the other learning the model's including problem-based learning, the project based learning, inquiry, STEM (Yennita \& Zukmadini, 2021; Ardianti et al., 2019; Marnita et al., 2020; Suana et al., 2019a; Setyoko \& Indriaty, 2018; Ramdani \& Badriah, 2018; Alfi et al., 2016; Husamah, 2015); blended learning is taught with the help of LMS such as Google Classroom, Schoology and Moodle (Sugiarti et al., 2021; Ardianti et al., 2019; Anggraeni et al., 2019; Ningsih et al., 2018; Suana et al., 2017); and blended learning with the help of social media such as WhatsApp, Instagram, and others (Sari \& Wahyudin, 2019; Suana et al., 2019b).

Blended learning that is taught as a learning model is applied through three syntaxs, namely seeking of information, the acquisition of knowledge and synthetizing of knowledge (Astuti \& Novita, 2019). Furthermore, the first stage in syntax includes searching for information from various available sources, the second stage students will work together to understand then interpret and communicate their ideas by utilizing technological facilities, then in the last stage students will form their knowledge through the process of assimilation and accommodation based on the results of discussions, analysis, and formulation of conclusions from the information they have obtained (Astuti \& Novita, 2019).

Blended learning that is learned by combining it with other learning models is carried out by following the syntax according to the learning model that has been selected. Furthermore, there is an organization of the syntax of the learning model, there is a syntax that is implemented in face-to-face learning and there is a syntax that will be implemented in online learning. According to Allen et al., (2007), if the design and implementation of learning is carried out $30-80 \%$ online, then learning is said to have implemented blended learning. Therefore, the various forms of implementation of blended learning aim to maximize the advantages of the learning environment in blended learning so that the expected learning objectives can be achieved.

The learning environment in blended learning has several advantages that can help students learn. Several advantages that have been synthesized from previous studies include: blended learning provides support in the self-paced learning process (Sandi, 2012; Hermawanto et al., 2013; Farida \& Indah, 2018), blended learning facilitate collaborative learning (support collaborative learning) (Putra \& Fitrayati, 2021; Wahyunita \& Subroto, 2021; Yennita \& Zukmadini, 2021), blended learning also supports ongoing discussion activities during learning (support discussion) (Ningsih et 
al., 2018; Suana et al., 2017; Suana et al., 2019a), as well as support for a blended learning environment that allows students to build their knowledge (support knowledge construct) (Syarif, 2012; Alfi et al., 2016; Suana et al., 2017; Farida \& Indah, 2018; Sugiarti et al., 2021).

Blended learning allows students to learn from various sources (Syarif, 2012; Alfi et al., 2016; Suana et al., 2017; Wright, 2017); and allows students to manage their learning (Sandi, 2012; Hermawanto et al., 2013; Farida \& Indah, 2018). The learning environment in blended learning also allows learners can access various learning resources such as learning videos, learning materials, student activity sheets, and other learning resources anytime and anywhere (Anggraeni et al., 2019; Sugiarti et al., 2021). Students can access online classes independently to review and re-learn material they have not understood (Anggraeni et al., 2019). The online learning environment in blended learning also allows learners can study in advance to prepare themselves before learning in face-toface classes is carried out (Ningsih et al., 2018). In other words, blended learning supports flexibility in learning.

Furthermore, blended learning supports collaborative activities in learning. Collaboration can occur in face-to-face classes or online classes (Putra \& Fitrayati, 2021), (Wahyunita \& Subroto, 2021). Students collaborate to complete assignments or to build a better understanding (Yennita \& Zukmadini, 2021). In addition, collaboration in blended learning can also occur due to discussion activities during learning.

Through discussion, students can exchange informations, ideas and knowledges with other students and with teachers. Blended learning provides opportunities for all students to be involved, and actively participate in discussions (Ningsih et al., 2018), (Suana et al., 2017). Students who tend to feel shy and lack confidence in discussing face-to-face classes will be able to be more flexible in discussions in online classes. Blended learning allows the formation of good communication between fellow students and between students and teachers (Suana et al., 2019a). The blended learning environment can also help teachers to monitor and ensure student activity during learning (Suana et al., 2019a; Yustina et al., 2020) so that teachers can know the progress of their student's learning.

Furthermore, the learning environment in blended learning can also be used to train students' thinking skills (Putra \& Fitrayati, 2021; Wahyunita \& Subroto, 2021; Anggraeni et al., 2019; Yennita \& Zukmadini, 2021). Students' thinking skills can be trained not only in face-to-face classes but also through online classes. The blended learning environment allows teachers to train students' critical thinking skills (Yennita \& Zukmadini, 2021; Sukma \& Priatna, 2021), because students can discuss without being limited by space and time (Anggraeni et al., 2019). The blended learning environment also provides a space for teachers to provide feedback on student learning progress (Yustina et al., 2020). Giving feedback is intended so that students become more enthusiastic about learning. Blended learning make teachers to develop ICT-based learning; active, creative, effective, interesting, and contextual (Lestari et al., 2016).

Based on the literature review conducted, blended learning has the characteristics of maximizing the advantages both of the face-to-face learning environment and the online learning the environment so that it is possible to support the student learning the process to increase learning motivation, increase mastery of concepts, and train students' thinking skills. 
Barriers to the Implementation of Blended learning

Blended learning has many benefits in supporting learning activities, both in terms of time, place, and the learning environment. In classes that apply blended learning, students generally meet in face-to-face learning, they can communicate with each other, and discuss in online learning. However, blended learning is not without obstacles and criticisms. From on the literature study from previous research, it is known that there are several obstacles in the implementation of blended learning, including the management of the blended learning environment requires careful planning (Farida \& Indah, 2018) so that learning activities can be carried out optimally. Furthermore, blended learning requires very diverse media, so if the facilities and infrastructure do not support it, it is difficult to implement (Husamah, 2014). In addition, the supporting facilities owned by students and schools such as computers and the internet are not evenly distributed, which makes it difficult for students to participate in online learning (Yustina et al., 2020; Suana et al., 2019a). Thus, it is necessary to understand the characteristics of students and the availability of supporting facilities and infrastructure before deciding to carry out learning with blended learning.

\section{Trends of Blended Learning Research}

Blended learning is a form of learning that integration of technology in it. The implementation of blended learning, both at school and university levels, is able to influence learning outcomes, motivation, mastery of concepts, reasoning, and critical thinking skills. Furthermore, by applying blended learning that is integrated into other learning models such as a problem based learning, project based learning, inquiry and STEM, it can improve critical thinking skills, improve creative thinking skills, and improve student learning outcomes so that it becomes a trend in the implementation of blended learning.

\section{Suggestions for Implementing Blended Learning}

Based on research trends of blended learning, suggestions can be made to use blended learning that is integrated with other learning models that are in accordance with the content of the particular material to be taught. For example, blended learning is integrated with a problem based learning model to improve students' critical thinking skills on biochemical material, blended learning is integrated with a project based learning model to improve students' creative thinking and critical thinking skills on environmental sustainable materials, and blended learning is integrated into the inquiry model to improve students' critical thinking skills on static electricity. In addition, it is also recommended the implementation of LMS-assisted blended learning to facilitate the arrangement of the online learning environment.

\section{CONCLUSION}

Based on the results of a literature review on the implementation of blended learning in learning activities, it can be concluded that blended learning is a method for a learning process that an interesting and flexible that can maximizing the benefits both face-toface learning environments and online learning environments to provide support for students' learning processes, thereby increasing learning motivation, increasing conceptual understanding, and training students' thinking skills. Implementation of blended learning is in the following ways: taught as a learning model, taught by combining it with other learning strategies or models, taught with the help of LMS, and 
taught with the help of social media. Opportunities for applications of blended learning are due to the support of student independent learning, collaborative learning, discussions anytime and anywhere, as well as supporting the construction of student understanding by providing a variety of widely accessible learning media. Therefore, blended learning supports activities that can train students' 21st century skills. The obstacles found in the implementation of blended learning require careful planning related to the availability of supporting facilities and infrastructure to apply blended learning in learning activities. Further researchers are advised to research the application of blended learning to improve 21st century skills known as 4C.

\section{ACKNOWLEDGEMENTS}

The author expresses the deepest gratitude to the Indonesian Endowment Fund for Education (LPDP) for providing a full scholarship to the first author, and the author would also like to express the deepest gratitude to the Provincial Government of West Nusa Tenggara for providing the opportunity to develop competence through learning the permit (Tugas Belajar) to the first author.

\section{REFERENCES}

Aji, R. H. S., Astuti, B., \& Saptono, S. (2021). The analysis of students' cognitive learning outcomes through the implementation of blended learning in junior high schools science. Journal of Innovative Science Education, 37(1), 1-6.

Alfi, C., Sumarmi, S., \& Amirudin, A. (2016). Pengaruh pembelajaran geografi berbasis masalah dengan blended learning terhadap kemampuan berpikir kritis siswa sma. Jurnal Pendidikan-Teori, Penelitian, dan Pengembangan, 1(4), 597-602.

Allen, I. E., Seaman, J., \& Garrett, R. (2007). Blending in: The extent and promise of blended education in the United States. The Sloan Consortium.

Anggraeni, A., Supriana, E., \& Hidayat, A. (2019). Pengaruh blended learning terhadap kemampuan berpikir kritis siswa sma pada materi suhu dan kalor. Jurnal Pendidikan, 4(6), 758-763.

Ardianti, S., Sulisworo, D., \& Pramudya, Y. (2019). Efektivitas blended learning berbasis pendekatan stem education berbantuan schoology untuk meningkatkan critical thinking skill pada materi fluida dinamik. Prosiding Seminar Nasional Pendidikan KALUNI, 2(1), 240246. https:// doi.org/10.30998/prokaluni.v2i0.67

Astuti, D. A. \&, \& Novita, D. (2019). Blended learning terhadap kemampuan komunikasi matematis. Prosiding Sendika, 5(1), 191-199.

Farida, A., \& Indah, R. P. (2018). Penerapan blended learning untuk peningkatan kemandirian belajar dan critical thinking mahasiswa. Jurnal Derivat: Jurnal Matematika Dan Pendidikan Matematika, 5(2), 19-27. https:// doi.org/10.31316/j.derivat.v5i2.138

Hermawanto, Kusairi, S., \& Wartono. (2013). Pengaruh blended learning terhadap penguasaan konsep dan penalaran fisika peserta didik kelas X. Jurnal Pendidikan Fisika Indonesia, 9(1), 67-76. https:// doi.org/10.15294/jpfi.v9i1.2582

Husamah. (2014). Pembelajaran bauran (blended learning). Jakarta: Prestasi Pustaka.

Husamah. (2015). Thinking skills for environmental sustainability perspective of new students of biology education department through blended project based learning model. Jurnal Pendidikan IPA Indonesia, 4(2), 110-119. https:/ / doi.org/10.15294/jpii.v4i2.3878

Isbandiyah, S., \& Sanusi, A. (2019). Modul penyusunan soal keterampilan berpikir tingkat tinggi (higher order thinking skills) biologi. Jakarta: Kementerian Pendidikan dan Kebudayaan.

Kemendikbud. (2019). Programme for international student assessment (PISA). Jakarta: Kementerian Pendidikan dan Kebudayaan.

Lestari, D., Mulyani, E. ., \& Susanti, R. (2016). Pengembangan perangkat blended learning 
sistem saraf manusia untuk meningkatkan keterampilan berpikir kritis. Journal of Innovative Science Education, 5(1), 83-93.

Marnita, Taufiq, M., Iskandar, \& Rahmi. (2020). The effect of blended learning problem-based instruction model on students' critical thinking ability in thermodynamic course. Jurnal Pendidikan IPA Indonesia, 9(3), 430-438. https://doi.org/10.15294/jpii.v9i3.23144

Ningsih, W. S. A., Suana, W., \& Maharta, N. (2018). Pengaruh penerapan blended learning berbasis schoology terhadap kemampuan berpikir kritis siswa. Konstan - Jurnal Fisika dan Pendidikan Fisika, 3(2), 85-93. https://doi.org/10.20414/konstan.v3i2.16

Nirahua, J., Taihuttu, J., \& Sopacua, V. (2020). Pengembangan bahan ajar berbasis blended learning dan critical thinking skill pada mata kuliah astrofisika dalam menyongsong era revolusi industri 4.0. Jambura Physics Journal, 2(1), 24-36. https://doi.org/10.34312/jpj.v2i1.6869

Putra, H. A. D., \& Fitrayati, D. (2021). Efektivitas model pembelajaran blended learning untuk meningkatkan keterampilan berpikir kritis peserta didik pada pelajaran ekonomi. Jurnal Ilmu Pendidikan, 3(4), 1765-1774. https:// doi.org/10.31004/edukatif.v3i4.676

Ramdani, D., \& Badriah, L. (2018). Korelasi antara kemampuan berpikir kritis dengan hasil belajar siswa melalui model pembelajaran inkuiri terbimbing berbasis blended learning pada materi sistem respirasi manusia. Jurnal Bio Educatio, 3(2), 37-44.

Safaruddin, S., Degeng, I., Setyosari, P., \& Murtadho, N. (2020). The Effect of PjBL with WBL Media and Cognitive Style on Studentsâ€TM Understanding and Science-Integrated Concept Application. Jurnal Pendidikan IPA Indonesia, 9(3), 384-395. doi:https://doi.org/10.15294/jpii.v9i3.24628

Sandi, G. (2012). Pengaruh blended learning terhadap hasil belajar kimia ditinjau dari kemandirian siswa. Jurnal Pendidikan dan Pengajaran, 45(3), 241-251. https://doi.org/http://dx.doi.org/10.23887/jppundiksha.v45i3.1839

Sani, R. A., \& Prayitno, W. (2020). Asesmen kompetensi minimum: Panduan penilaian untuk guru sekolah (sd, smp, sma, smk) dan madrasah. Bandung: PT. Remaja Rosdakarya.

Sari, F. M., \& Wahyudin, A. Y. (2019). Undergraduate students' perceptions toward blended learning through instagram in english for business class. International Journal of Language Education, 3(1), 64-73. https://doi.org/10.26858/ijole.v1i1.7064

Setyoko, S., \& Indriaty, I. (2018). Penerapan pembelajaran problem based learning berbasis blended learning terhadap hasil belajar kognitif dan motivasi mahasiswa. Jurnal Pendidikan Biologi, 7(3), 157. https://doi.org/10.24114/jpb.v7i3.10433

Singh, H., \& Reed, C. (2001). A white paper: Achieving success with blended learning. Centra Software.

Suana, W., Istiana, P., \& Maharta, N. (2019a). Pengaruh penerapan blended learning pada materi listrik statis terhadap kemampuan berpikir kritis siswa. Jurnal Pendidikan Sains (Jps), 7(2), 129-135. https://doi.org/10.26714/jps.7.2.2019.129-136

Suana, W., Maharta, N., Nyeneng, I. D. P., \& Wahyuni, S. (2017). Design and implementation of schoology-based blended learning media for basic physic I course. Jurnal Pendidikan IPA Indonesia, 6(1), 170-178. https:// doi.org/10.15294/jpii.v6i1.7205

Suana, W., Raviany, M., \& Sesunan, F. (2019b). Blended learning berbantuan whatsapp: Pengaruhnya terhadap kemampuan berpikir kritis dan kemampuan pemecahan masalah. Gravity: Jurnal Ilmiah Penelitian dan Pembelajaran Fisika, 5(2), 37-45. https://doi.org/10.30870/gravity.v5i2.4990

Sugiarti, D. R., Munzil, \& Siti Marfu'ah. (2021). Developing multiple representation's teaching materials assisted by blended learning to improve student's science process skills. AIP Conference Proceedings, 2330(1), 1-5. https:/ / doi.org/10.1063/5.0043275

Sukma, Y., \& Priatna, N. (2021). The effectiveness of blended learning on students' critical thinking skills in mathematics education: A literature review. Journal of Physics: Conference Series, 1806(1), 1-5. https:// doi.org/10.1088/1742-6596/1806/1/012071

Susilowati, E., Dewantara, D., Suyidno, \& Winarno, N. (2021). Pengaruh blended learning 
terhadap keterampilan berpikir kritis dan keterampilan berpikir kreatif. Prosiding Seminar Nasional Lingkungan Lahan Basah, 6(2), 1-5.

Syarif, I. (2012). Pengaruh model blended learning terhadap motivasi dan prestasi belajar siswa SMK. Jurnal Pendidikan Vokasi, 2(2), 234-249. https://doi.org/10.21831/jpv.v2i2.1034

Utomo, S. W., \& Wihartanti, L. V. (2019). Penerapan strategi blended learning untuk meningkatkan kemampuan berpikir kritis mahasiswa pada era revolusi industri 4.0. Kwangsan: Jurnal Teknologi Pendidikan, 7(1), 30-44. https://doi.org/10.31800/jtp.kw.v7n1.p30--44

Wahyunita, I., \& Subroto, W. T. (2021). Efektivitas model pembelajaran blended learning dengan pendekatan stem dalam upaya meningkatkan kemampuan berfikir kritis peserta didik. Edukatif: Jurnal Ilmu Pendidikan, 3(3), 1010-1021.

Widana, I. N. S., Sumaryani, N. P., \& Pradnyawati, N. L. W. A. (2018). Memicu kemampuan berpikir kritis dan hasil belajar biologi melalui model blended learning berbantuan komik digital. Emasains, 7(1), 38-48.

Wright, B. M. (2017). Blended learnings student perception of face-to-face and online EFL lessons. Indonesian Journal of Applied Linguistics, 7(1), 64-71. https://doi.org/10.17509/ijal.v7i1.6859.

Yennita, Y., \& Zukmadini, A. Y. (2021). Problem-based learning (PBL) and blended learning in improving critical thinking skills and student learning activities in biochemistry courses. Journal of Physics: Conference Series, 1731(1), 1-8. https://doi.org/10.1088/17426596/1731/1/012007

Yustina, Syafii, W., \& Vebrianto, R. (2020). The effects of blended learning and project-based learning on pre-service biology teachers' creative thinking skills through online learning in the covid-19 pandemic. Jurnal Pendidikan IPA Indonesia, 9(3), 408-420. https://doi.org/10.15294/jpii.v9i3.24706

\footnotetext{
*Eka Yulia Syahrawati, S.Pd. (Corresponding Author)

Postgraduate of Science Education,

Universitas Negeri Surabaya,

Gedung CPD, Jl. Lidah Wetan, Surabaya 60231, Indonesia

Email: eka.20002@mhs.unesa.ac.id
}

Prof. Dr. Endang Susantini, M.Pd.

Department Postgraduate of Science Education,

Universitas Negeri Surabaya,

Gedung CPD, Jl. Lidah Wetan, Surabaya 60231, Indonesia

Email: endangsusantini@unesa.ac.id

\section{Dr. Sifak Indana, M.Pd.}

Department Postgraduate of Science Education,

Universitas Negeri Surabaya,

Gedung CPD, Jl. Lidah Wetan, Surabaya 60231, Indonesia

Email: sifakindana@unesa.ac.id 